\title{
STUDY ON THE INFLUENCE OF POSITIONING STRATEGY, PRODUCT QUALITY, SERVICE QUALITY AND CORPORATE IMAGE TO DECISION OF SAVING AT BANK BJB TEGAL BRANCH
}

\author{
Sandy Baytu Thauhid ${ }^{1}$ \\ Susilo Toto Raharjo ${ }^{2}$ \\ Harry Soesanto ${ }^{3}$
}

\begin{abstract}
1,2,3 Master of Management, Faculty of Economics and Business, Diponegoro University
\end{abstract}

\begin{abstract}
The position of bank BJB based on Total DPK in December 2014 rise to the category national public bank, but it is different from Total DPK in the branch of bank BJB in Tegal, in the same period the strategy of bank BJB Tegal accumulate DPK (Dana Pihak Ketiga), by increasing product sales of cheap deposits as well as savings BJB Tandamata. This study analyzes several factors that thought to have an influence on the decisions to save, there are positioning, serving quality, product quality, and corporate image.

The population of the respondents in this study as many as 120 customers. In this research using purposive sampling technique.

The research results show that the positioning strategy has a positive effect on saving. While the quality of the product has no positive effect on a decision on saving. And the quality of the product has not a positive effect on the strategy of positioning. The quality of service has a positive influence on the positioning strategy. And the quality of service has a positive effect on the corporate image. And the test results of the corporate image of saving have a positive influence. So that it can be summed up in this research decision saving the customer at a bank $B J B$ branch Tegal is not affected by the quality of the products from the Tandamata BJB savings.
\end{abstract}

Keywords: positioning strategy, product quality, service quality, corporate image, saving decision.

\section{INTRODUCTION}

Bank Pembangunan Daerah Jawa Barat \& Banten (Bank BJB) do strategy transformation to develop the existence in order to survive in this era of continues 
technology to advance rapidly. That is done so that it can always do innovation and change, example the changing of the company logo. The phenomenon of changing of the bank's logo and BJB has a strategy to go ahead and provide the best service for its customers, according to the vision of bank BJB "become the 10 largest banks and performs well in Indonesia." So it is a necessary expansion of the market to exit from territory West Java and Banten".

\section{Figure 1}

\section{The Position of BJB bank based on Assets Period December 2014}

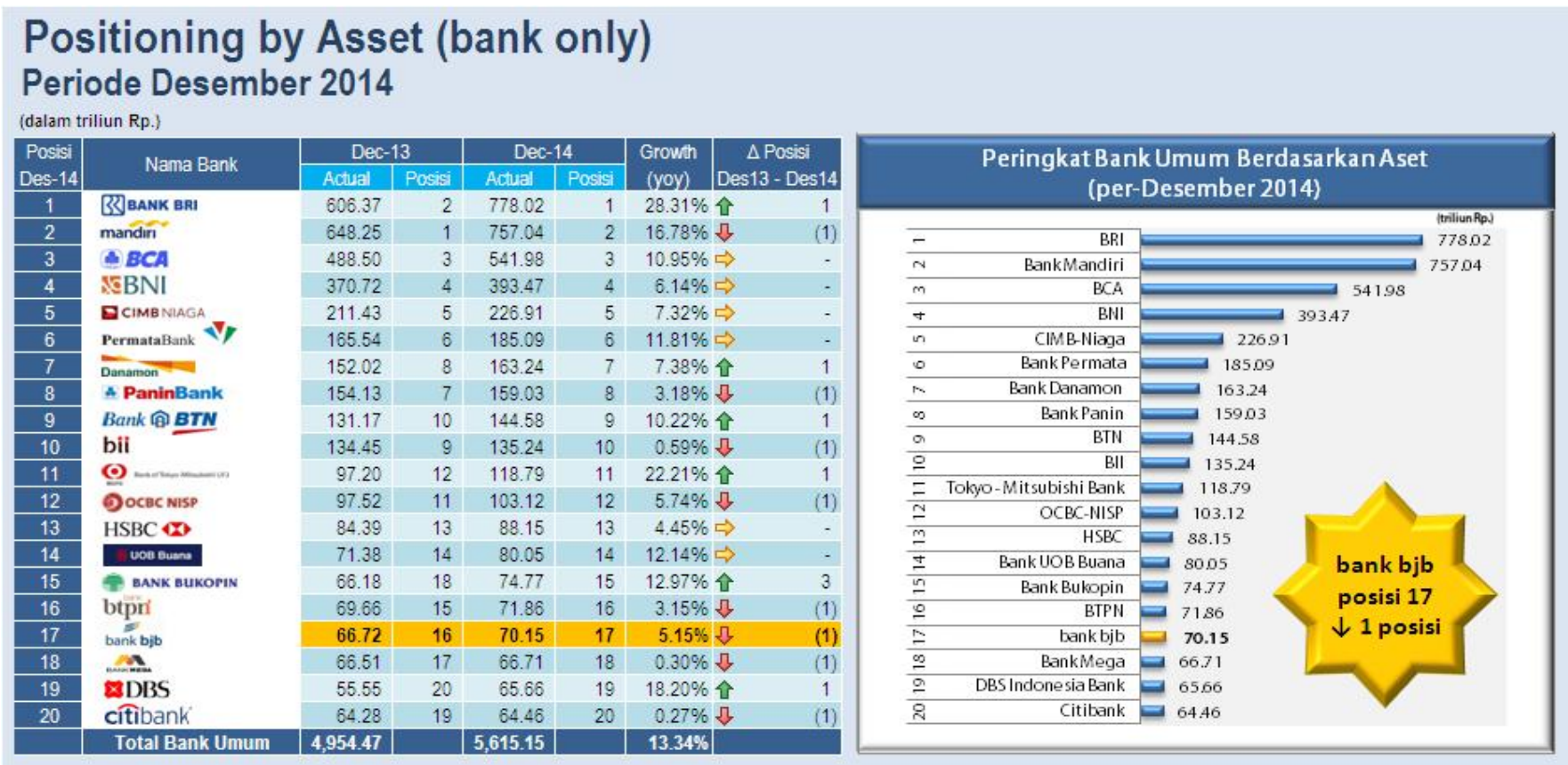

The position asset of bank BJB in the December 2014 period has been decreasing, but at one point positioning, DPK in the same period has increased three points to national public bank category. This shows that competition in the banking business has increased, so bank BJB should be more aggressive in grabbing market segment. To grab the market segment of the national bank, bank BJB has to become the primary choice as a means to Transaction.

Associated with the conditions that exist on the branch of the bank BJB Tegal then needs to be studied that variables that so it can be made an attempt to solve the problem. This needs to be researched for the variable that influences the decision to save on the Branch of bank BJB Tegal. So the purpose of this study is to analyze the influence of the strategy of positioning, product quality, service quality, corporate image against the decision of saving. 


\section{LITERATURE REVIEW}

According to Mowen (2002) that the study of the purchase and the Exchange process include income, consumption, and disposal of products, services and experiences called consumer behavior. Marketing strategies developed by analyzing the titler-factor that have an influence on consumer behavior. Consumer behavior, according to The American Marketing Association in Setiadi, 2003, it is a dynamic relationship between affection \& cognition, attitude and the circumstances surrounding them. There is three important consumers behavior based on these explanations:

1. Fast-changing consumer Behavior over the time, so from that consumer behavior it is dynamic.

2. Consumer behavior including the relationship between affection (feelings) and cognition (thought), attitudes and events around us.

3. The marketer acted to make exchanging with consumers by a good strategy because consumer behavior in it includes the process of Exchange.

4. Consumer behavior in it includes the process of Exchange.

Positioning that is concerning how to gain the trust of a business consumer (Kertajaya, 2004:106). To create a unique differentiation in the minds of consumers so that the resulting the product or service is superior compared to a competitor's product or service then it takes the right positioning strategy. because in the banking industry have intense competition in positioning.

The overall image of a product or service in its ability to satisfy the needs of consumers who expressed or implied is the quality of the product (Kotler, 2005:49). Customer satisfaction can be expressed when the results of their evaluation showed that the products they use have a good quality (Laupiyoadi, 2001:158).

According to Zeithaml and Bitner (2005:28), the entire economic activity with output in addition to a product in the sense of physical, consumed and produced at the same time as well as providing added value and in principle the intangible for the first buyers.

Service quality is often defined as a fulfillment of the desires of the customers to meet their expectations. In the considering the quality of the service, according to Gwinner et. Al (1998) the company is able to understand the customer who always faced on ways to the position themselves. The quality of service is important because it can increase the profitability and success of the company (Aydin and Ozer, 2004).

The image of corporate has an ability which can add the strength of the company to the products and services offered, and it is beyond the capability of 
the company. According to Sitinjak (2005), so that the image of the companyspecific, effective and satisfactory can be reached according to the wishes of the company, then the efforts of marketing and the communication must be presented on a consistent basis. Ban (1987) added one more P than 4 P's (Product, Price, Place, Promotion) commonly known as the marketing mix, it is "Public Image".

A decision to determine the action of two or more alternative options is called with a purchasing decision. According to Peter \& Olson (2000), the process of integration that combined knowledge to evaluate two or more alternative behaviors and choosing one of them called the purchasing decisions.

Figure 2

Theoretical Thinking Framework

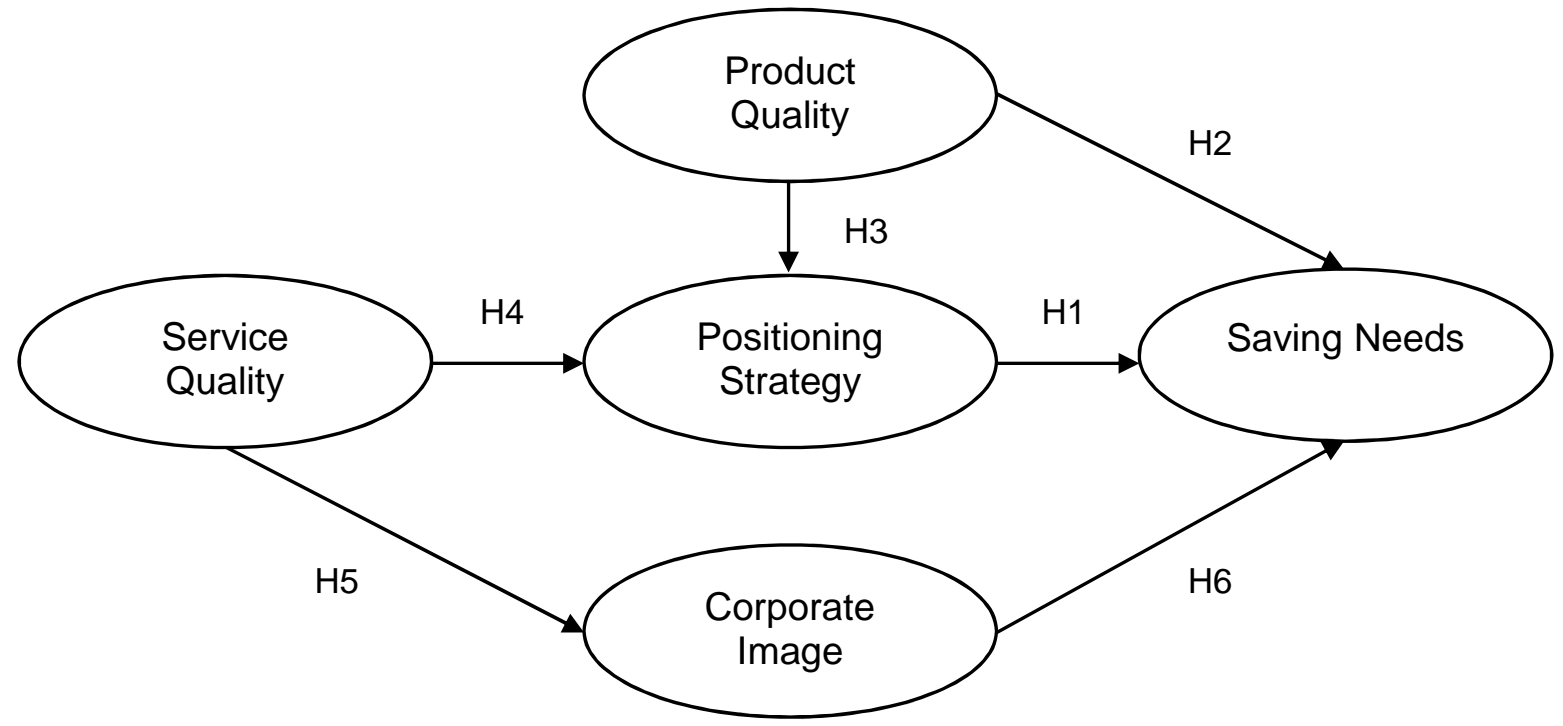

Source: from a variety of journals, and developed in this research

\section{RESEARCH METHOD}

\section{Population and Sample}

In this research, a population that is taken is the customer which savings BJB Tandamata using purposive sampling technique. This means subjects taken are already selected according to the criteria on this research (Sugiyono, 2010).

Hair et al in Ferdinand, (2002) found that the appropriate sample size is between 100-200. The sample has specified in this research as many as 120 people customer. When the sample size becomes too large for example more than 400 so the method becomes into "very sensitive" that too hard to get a good size of Goodness Fit. 


\section{Data Collection Method}

The closed inquiry methods used in the collection of data in this study, using a score scale Linkert as in table 1 below:

Table 1

Likert Type Scale

\begin{tabular}{|c|c|c|c|c|}
\hline 1 & 2 & 3 & 4 & 5 \\
\hline $\begin{array}{c}\text { Very } \\
\text { Disagree } \\
\text { (STS) }\end{array}$ & $\begin{array}{c}\text { Disagree } \\
\text { (TS) }\end{array}$ & $\begin{array}{l}\text { Normal } \\
\text { (N) }\end{array}$ & $\begin{array}{c}\text { Agree } \\
\text { (S) }\end{array}$ & $\begin{array}{c}\text { Very } \\
\text { Agree } \\
\text { (SS) }\end{array}$ \\
\hline
\end{tabular}

\section{DISCUSSION}

\section{Testing The Assumptions Of Structural Equation Models (SEM)}

For ranges that were used to test the normality of the data with the level of significance from 0.01 must be made \pm 2.58 . At a glance, we can see at the end of the $\mathrm{CR}$ value in the table of multivariate. Table 2 showing results data from normality testing in this research. 
Table 2

Evaluation of The Normality Of Data

\begin{tabular}{|c|c|c|c|c|}
\hline Variable & Min $\max$ skew & cr. & kurtosis & cr. \\
\hline$\overline{816}$ & $1,0005,000-, 211$ &,- 946 &, 160 &, 358 \\
\hline $\mathrm{x} 15$ & $1,0005,000-, 043$ &,- 190 &,- 478 & $-1,06$ \\
\hline xl4 & $1,0005,000-, 128$ &,- 574 &,- 591 & $-1,32$ \\
\hline 813 & $1,0005,000-, 181$ &,- 809 &,- 446 &,- 996 \\
\hline 817 & $1,0005,000,052$ &, 233 &,- 213 &,- 477 \\
\hline 818 & $1,0005,000-, 135$ &,- 605 &,- 136 &,- 305 \\
\hline 819 & $1,000 \quad 5,000-, 232$ & $-1,037$ &,- 034 &,- 075 \\
\hline 820 & $1,0005,000-, 183$ &,- 820 &,- 169 &,- 377 \\
\hline$x 8$ & $1,0005,000-127$ &,- 570 &,- 793 & $-1,77 \vdots$ \\
\hline 87 & $1,0005,000,285$ & 1,273 &,- 462 & $-1,03$ \\
\hline 86 & $1,0005,000-, 241$ & $-1,077$ &,- 449 & $-1,004$ \\
\hline 85 & $2,0005,000,339$ & 1,514 &,- 355 &,- 794 \\
\hline $\mathrm{x} 12$ & $1,0005,000-, 017$ &,- 075 &,- 755 & $-1,68 \mathrm{~s}$ \\
\hline$x 11$ & $1,0005,000-, 164$ &,- 733 &,- 846 & $-1,89$ \\
\hline 810 & $1,0005,000,080$ &, 358 &,- 949 & $-2,12 z$ \\
\hline 89 & $1,0005,000,001$ &, 004 &,- 831 & $-1,858$ \\
\hline 84 & $1,0005,000-338$ & $-1,514$ &,- 012 &,- 027 \\
\hline 83 & $1,0005,000-275$ & $-1,231$ &,- 011 &,- 024 \\
\hline 82 & $2,0005,000,195$ & 871 &,- 711 & $-1,590$ \\
\hline $\mathrm{xl}$ & $2,0005,000,142$ &, 635 &,- 542 & $-1,21 \equiv$ \\
\hline Multivariate & & & $-5,521$ & $-1,016$ \\
\hline
\end{tabular}

Source: Research data are processed, 2017 
The value of $C R$ from the results of the data processing as shown in table 2 are outside the range that required \pm 2.58 , thus data in this research have been working at normal distribution. For more easily we can see on the last value from the column values of the multivariate CR 1.019 it is at the range of \pm 2.58 .

The results of the processing data obtained in this analysis are not found in the existence of the outlier that showed the results of the maximum distance from 33.39. It was under the value of the chi-square levels on $<45.3140 .001$ and nondegree of 20 corresponds to the number of the indicator.

\section{Results of The Feasibility Testing Model}

Testing the hypothesis on the hypothesis of the model showed that this model corresponds to the data or fit the data used in the study as shown in table 3:

Table 3

The SEM Analysis Results

\begin{tabular}{lc|c|c}
$\begin{array}{c}\text { Goodness of Fit } \\
\text { Indeks }\end{array}$ & Cut-off Value & $\begin{array}{c}\text { The Results Of } \\
\text { The Analysis }\end{array}$ & $\begin{array}{c}\text { The } \\
\text { Evaluation } \\
\text { Model }\end{array}$ \\
\hline Chi-Square & $<193,713 \mathrm{df} 163$ & 144,802 & Good \\
\hline Probability & $\geq 0.05$ & 0,844 & Good \\
\hline RMSEA & $\leq 0.08$ & 0,001 & Good \\
\hline GFI & $\geq 0.90$ & 0,895 & Marginal \\
\hline AGFI & $\leq 0.90$ & 0,865 & Marginal \\
\hline CMIN/df & $\geq 2,00$ & 0,888 & Good \\
TLI & $\geq 0.95$ & 1,023 & Good \\
\hline CFI & 1,000 & Good
\end{tabular}

Source: Research data are processed, 2017

After all the assumptions can be finished, then it will be done a testing hypothesis as proposed on testing 6 hypothesis on this research was conducted based on the value of the Critical Ratio (CR) from a relationship of causality from the results of the processing of SEM. 
Table 4

Standardized Regression Weight

\begin{tabular}{|c|c|c|c|c|c|c|c|}
\hline & & & Estimate & S.E. & C. $\mathbf{R}$. & $\mathbf{P}$ & Label \\
\hline strategi_positioning & $<$ & kualitas_produk & -.109 & .368 & -.297 & .767 & par_17 \\
\hline strategi_positioning & $<$ & kualitas_layanan & .495 &, 187 & 2,646 & .008 & par_1s \\
\hline citra_perusahaan & $<$ & kualitas_layanan & .422 & .145 & 2,908 & .004 & par_19 \\
\hline keputusan_menabung & $<$ & citra_perusahaan & .293 & .094 & 3.126 & .002 & par_20 \\
\hline keputusan_menabumg & $<$ & strateg_positioning & .142 & .068 & 2,089 & .037 & par_21 \\
\hline keputusan_menabung & $<$ & kualitas_produk & .091 & .240 & .381 & .703 & par_22 \\
\hline
\end{tabular}

\section{CONCLUSION}

\section{Summary of The Hypothesis}

1. The results test of the positioning strategy of saving has a positive influence.

2. The results test of quality products of saving has no influence.

3. The results test of product positioning strategy has no influence

4. The results test of service against the strategy of positioning has positive influence

5. The results test of service against corporate image has a positive influence

6. The results test of the influence test of the corporate image of saving has positive influence

\section{Future Research Agenda}

The Results of the study were able to become the reference for the research to come up with a look at some of the output generated from this research and add to the endogenous variable of the decision to saving.

\section{REFERENCES}

Armstrong, G., and Kotler, P., 2008, Principles of Marketing 12th ed, New Jersey: Prentice Hall.

Cooper, Donald R., dan William Emory., 1998, Metode Penelitian Bisnis, Jakarta: Erlangga. 
Ferdinand, Augusty, 2006, Metode Penelitian Manajemen, Badan Penerbit Universitas Diponegoro, Semarang.

Gujarti, Doromar., 1995, Dasar-dasar Ekonometrika. Jakarta : Erlangga.

Hair, Josep F., Anderson, Rolpp E Tatham, Ronald, L., Black, William., 1998. Multivariate Data Analysis, Third Edition, Prentice Hall.

Kertajaya, Hermawan., 2004, Mark Plus Strategy, Jakarta: Gramedia Pustaka Utama.

Kotler, Philip., 2005, Manajemen Pemasaran: Analisis, Perencanaan, Implementasi, dan Kontrol, Jakarta : Prenallindo.

Laupiyoadi, Rambat., 2001, Manajemen Pemasaran Jasa (Teori dan Praktik), Jakarta : PT. Salemba Emban Patria.

Zineldin, M., 1996, Bank Strategic Positioning and Some Determinants of Bank Selection, International Journal of Bank Marketing, Vol. 14. No. 6, pp 12-22. 